\title{
Synthesis of Novel Naphthoquinone-Spermidine Conjugates and their Effects on DNA-Topoisomerases I and II- $\alpha$
}

\author{
Andréa S. Cunha, ${ }^{a}$ Edson L. S. Lima, ${ }^{*, a}$ Angelo C. Pinto, ${ }^{* a}$ Andressa Esteves-Souza, ${ }^{a}$ Aurea Echevarria, ${ }^{b}$ \\ Celso A. Camara, ${ }^{c}$ Maria D. Vargas ${ }^{*, d}$ and José C. Torres ${ }^{e}$ \\ ${ }^{a}$ Instituto de Química, Universidade Federal do Rio de Janeiro, 21945-970 Rio de Janeiro - RJ, Brazil \\ ${ }^{b}$ Departamento de Química, ICE, Universidade Federal Rural do Rio de Janeiro, Seropédica - RJ, Brazil \\ ${ }^{c}$ Laboratório de Tecnologia Farmacêutica, Universidade Federal da Paraíba, CP 5009, 58051-970 \\ João Pessoa - PB, Brazil \\ ${ }^{d}$ Instituto de Química, Universidade Federal Fluminense, Campus do Valonguinho, 24020-150 \\ Niterói - RJ, Brazil \\ ${ }^{e}$ Centro Federal de Educação Tecnológica de Química de Nilópolis, Unidade Nilópolis, 26530-060 \\ Nilópolis - RJ, Brazil
}

\begin{abstract}
Novos derivados do lapachol 2, nor-lapachol 3 e da lausona 4 foram sintetizados através do deslocamento nucleofílico das metoxinaftoquinonas $\mathbf{2 a}$, 3a e 4a pela poliamina (PA) $N^{1}$-Boc$N^{5}$-Bn-espermidina 1a. Os produtos, $\mathbf{2 b}, \mathbf{3 b}$ e $\mathbf{4 b}$, respectivamente, foram obtidos em bons rendimentos e caracterizados por métodos espectroscópicos e analíticos. Os ensaios preliminares de inibição das enzimas topoisomerases (topo) I e II- $\alpha$ mostraram-se promissores: todos os compostos (1a $\mathbf{2 b}, \mathbf{3 b}$ e $\mathbf{4 b}$ ) inibiram a atividade catalítica da enzima topo II- $\alpha$ na dose de 2 $\mu \mathrm{M}$. Considerando que somente a PA 1a não inibiu a atividade da enzima na dose de $0,2 \mu \mathrm{M}$, as naftoquinonas apresentam-se como fragmentos em potencial para melhorar a atividade de PAs. Nenhum dos compostos inibiu a topo I na dose de $200 \mu \mathrm{M}$.
\end{abstract}

Novel derivatives of lapachol 2, nor-lapachol $\mathbf{3}$ and lawsone $\mathbf{4}$ have been synthesized by nucleophilic displacement of the methoxynaphthoquinones $\mathbf{2 a}, \mathbf{3 a}$ and $\mathbf{4 a}$ with the polyamine (PA) $N^{1}$-Boc- $N^{5}$-Bn-spermidine 1a. The respective products $\mathbf{2} \mathbf{b}-\mathbf{4} \mathbf{b}$ were obtained in good yields and characterized by spectroscopic and analytical methods. The inhibitory action of these naphthoquinone-PA conjugates on DNA-topoisomerases (topo) I and II- $\alpha$ was evaluated by relaxation assay of supercoiled DNA plasmid. All compounds $(\mathbf{1 a} \mathbf{2} \mathbf{b}, \mathbf{3 b}$ and $\mathbf{4 b})$ presented significant inhibition of topo II- $\alpha$ catalytic activity at the $2 \mu \mathrm{M}$ dose. Considering that only PA 1a did not inhibit the enzyme catalytic activity at the $0.2 \mu \mathrm{M}$ dose, the appended naphthoquinone moiety acts as a "value added" fragment. Compounds $\mathbf{1 a} \mathbf{2 b}, \mathbf{3 b}$ and $\mathbf{4 b}$ did not inhibit the enzyme DNA-topo I at the $200 \mu \mathrm{M}$ dose.

Keywords: spermidine, lapachol, lawsone, nor-lapachol, DNA-topoisomerase II- $\alpha$

\section{Introduction}

Polyamines (PAs) spermidine, spermine and putrescine occur in the cells of living organisms where they fulfill an array of physiological roles. ${ }^{1}$ Because they are involved in optimum growth and replication of various cell types, and are present in higher concentrations in rapidly proliferating cells ${ }^{2}$ they were identified as potential targets for the

*e-mail: mdvargas@vm.uff.br development of anticancer drugs. Initial efforts were focused on the design and synthesis of selective inhibitors of the PA biosynthetic enzymes however their action was not sufficient to inhibit tumor growth. ${ }^{3}$ The discovery that tissues with a high demand of PAs contain active polyamine transporter (PAT) for importing exogenous PAs ${ }^{4}$ redirected the focus of interest to the PA uptake system from the cellular environment, and several potent inhibitors became known. ${ }^{5}$ Anticancer therapies have tried to use the PAT to convey citotoxic and genotoxic agents to rapidly proliferating cells. ${ }^{6}$ 
Currently, the most actively pursued approach is based on tumor growth inhibition by cytotoxic structural analogues of the natural PAs, however the PA transport system also offers the possibility to improve transport and accumulation by tumors of compounds which are tethered to PA structures. One of the recent strategies involved the grafting of PAs onto DNA intercalators ${ }^{7}$ (e.g. linear tricyclic systems) whose primary target is a DNA topoisomerase enzyme., ${ }^{6,8}$

As part of our interest in the synthesis of $\mathrm{PAs}^{9}$ and in the preparation of aminonaphthoquinone derivatives with pharmacological activities, ${ }^{10,11}$ we became interested in linking spermidine (1) to lapachol (2), nor-lapachol (3) and lawsone (4). The prenyl naphthoquinone $\mathbf{2}$ is readily isolated from several species of Tabebuia sp (Bignoniaceae) abundant in South America, and derivative $\mathbf{3}$ is obtained from $\mathbf{2}$ by the Hooker oxidative degradation. ${ }^{12}$ A number of synthetic derivatives of lapachol, such as mono-(arylimines)- $O$ quinones derived from $\beta$-lapachone showed cytotoxicity against human cancer cells. ${ }^{13,14}$ Naphthoquinones related to lapachol 2 have been shown to exhibit notable cancer preventive potential. ${ }^{15}$ Furthermore, various amine derivatives of $2^{11}$ have been shown to interact with DNA. ${ }^{16}$

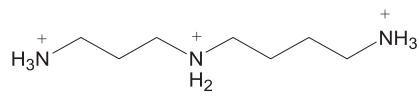

(1) spermidine

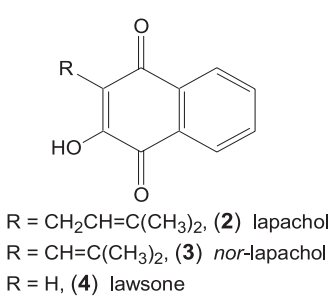

In an earlier communication ${ }^{9}$ we described a protocol for selective handling of spermidine amino groups. We report herein the coupling of a protected derivative of spermidine with the methoxylated derivatives of compounds 2-4 to yield the first naphthoquinones tethered to a PA.

\section{Results and Discussion}

\section{Synthesis of the spermidine-quinone conjugates}

The novel spermidine-quinone conjugates were synthesized as follows: $i$ ) methylation of lapachol $\mathbf{2}$ and nor-lapachol 3 with dimethylsulphate in acetone and potassium carbonate as described previously, to yield $\mathbf{2 a}$ $(77 \%)^{10}$ and $\mathbf{3 a}(71 \%),{ }^{11}$ respectively, and synthesis of methoxylawsone $\mathbf{4 a}$ from the sodium salt of 1,2naphthoquinone-4-sulfonic acid; ${ }^{17} \mathrm{ii}$ ) preparation of the protected derivative of spermidine 1a in a four-step synthesis; ${ }^{9}$ iii) nucleophilic displacement of the methoxyquinones $\mathbf{2 a}, \mathbf{3 a}$ and $\mathbf{4 a}$ with compound $\mathbf{1 a}$ (Scheme 1).

The reaction of $\mathbf{1 a}$ with methoxylapachol $\mathbf{2 a}$ under the conditions used for the synthesis of amine derivatives of lapachol, i.e. in methanol, under reflux, did not occur after $24 \mathrm{~h}$, according to TLC, however, when it was carried out in the same solvent in a sealed tube, at $90{ }^{\circ} \mathrm{C}$ for $20 \mathrm{~h}$, the desired product $\mathbf{2 b}$ was obtained $75 \%$ yield (Scheme 1). The reactions of $\mathbf{1 a}$ with the other methoxynaphthoquinones were then carried out under the same conditions and the respective substitution products $\mathbf{3 b}$ and $\mathbf{4 b}$ were also obtained in 61 and $98 \%$ yields, respectively. These compounds were characterized by analytical and spectroscopic methods. ${ }^{18}$ Their ${ }^{1} \mathrm{H}$ and ${ }^{13} \mathrm{C}$ NMR spectra showed clearly the naphthoquinone hydrogen and carbon signals, as well as those of the protected spermidine moiety.

\section{Relaxation assays of DNA topoisomerases (topo) I and II- $\alpha$}

The conversion of pBR322 supercoiled plasmid DNA to the relaxed form by the enzymes topo I and II- $\alpha$ was

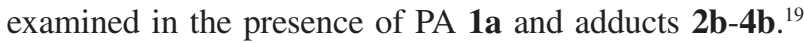
DNA topoisomerases are enzymes that modulate the topological state of DNA. They are targets for many effective drugs in cancer treatment. ${ }^{20}$

The effects of the compounds on the catalytic activity of DNA topo II- $\alpha$ enzyme were observed in the relaxation assays using pBR322 in the presence of ATP. ${ }^{21}$ PA 1a and conjugates $\mathbf{2 b}, \mathbf{4 b}$ and $\mathbf{3 b}$ were evaluated at $2 \mu \mathrm{M}$ (lanes $4-7$, respectively) and $0.2 \mu \mathrm{M}$ (lanes $8-11$, respectively) (Figure 1). All compounds presented significant inhibition of topo II- $\alpha$ catalytic activity at the $2 \mu \mathrm{M}$ dose. Etoposide was used as the positive control. Interestingly, at the 0.2 $\mu \mathrm{M}$ dose, only PA 1a did not inhibit the enzyme catalytic activity. Since only partial inhibition of the enzyme activity by lapachol $\mathbf{2}$ has been observed at the $200 \mu \mathrm{M}$ dose,${ }^{17}$ it is clear that the PA appendage has led to a

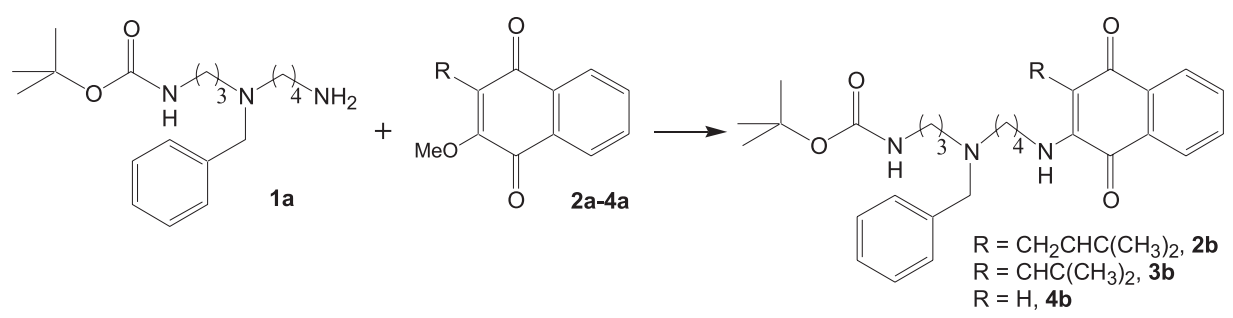

Scheme 1. 
dramatic decrease in the concentration of the adduct $\mathbf{2} \mathbf{b}$ necessary for inhibition of the enzyme activity. In contrast, none of the compounds inhibited the enzyme DNA-topo I at the $200 \mu \mathrm{M}$ dose.

$\begin{array}{lllllllllll}11 & 10 & 9 & 8 & 7 & 6 & 5 & 4 & 3 & 2 & 1\end{array}$

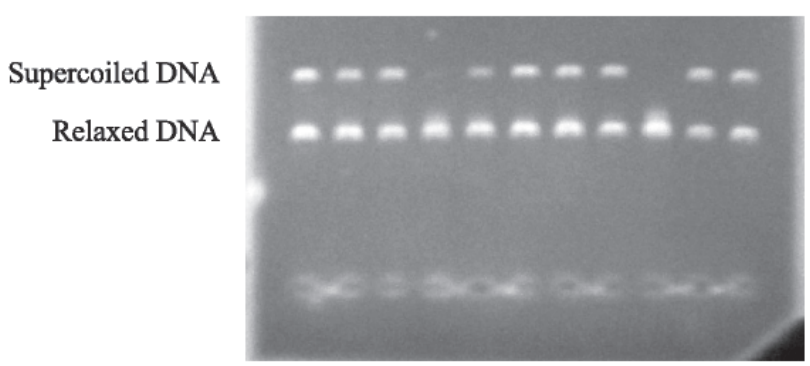

Figure 1. All lanes contain $0.25 \mu \mathrm{g}$ of the DNA (pBR322) and 1.0 unit of topo II- $\alpha$, with the exception of Lane 2. Lane 1: etoposide $(2 \mu \mathrm{M})$. Lane 2: negative control (pBR322 only). Lane 3: positive control (pBR322 and topo II- $\alpha$ ). Lane 4: PA 1a $2 \mu \mathrm{M}$; Lane 5: lapachol conjugate $2 \mathbf{b} 2 \mu \mathrm{M}$. Lane 6: lawsone conjugate 4b $2 \mu \mathrm{M}$. Lane 7: nor-lapachol conjugate $\mathbf{3 b}$ $2 \mu \mathrm{M}$. Lane 8: PA 1a $0.2 \mu \mathrm{M}$; Lane 9: lapachol conjugate $2 \mathbf{b} 0.2 \mu \mathrm{M}$. Lane 10: lawsone conjugate $4 \mathbf{b} 0.2 \mu \mathrm{M}$. Lane 11: nor-lapachol conjugate 3b $0.2 \mu \mathrm{M}$.

\section{Conclusions}

Although a number of PA conjugates have been described in the literature, ${ }^{6,8,22-23}$ to our knowledge, these are the first naphthoquinone spermidine adducts known to date. Preliminary results of the relaxation assays of DNA topo I and II- $\alpha$ indicate that the enzyme topo II- $\alpha$ is a target of PA-naphthoquinone conjugates $\mathbf{2 b}-\mathbf{4 b}$ at relatively low concentrations, and also point to the importance of the naphthoquinone moiety in improving the inhibitory activity of PA 1a. Further biological evaluation is in progress to determine the potency of these compounds. Considering the large spectra of pharmacological activities shown by lapachol and analogous naphthoquinones, studies are in progress to assess other pharmacological activities of compounds $\mathbf{2 b - 4 b}$.

\section{Acknowledgments}

The authors thank CNPq (Conselho Nacional de Desenvolvimento Científico e Tecnológico), CAPES (Coordenadoria de Apoio à Pesquisa do Ensino Superior) PADCT-FAPERJ and FAPERJ-PRONEX for research grants and fellowships.

\section{References}

1. Cohen, S. S.; A Guide to the Polyamines; New York: Oxford University Press, 1998.

2. Tabor, C. W.; Tabor, H.; Annu. Rev. Biochem. 1984, 53, 749.
3. Seiler, N.; Curr. Drug Targets 2003, 4, 537.

4. Cutlis, P. M.; Green, R. E.; Mereson-Davies, L; Travis, N; Chem. Biol. 1999, 6, 717.

5. Seiler, N.; Pharmacol. Ther. 2005, 107, 99.

6. Phanstiel, O. IV; Price, H. L.; Juusola, J.; Kline, M.; Shah, S. M.; J. Org. Chem. 2000, 65, 5590 and references therein.

7. Nelson, E. M.; Tewey, K. M.; Liu, L. F.; Proc. Natl. Acad. Sci. U.S.A. 1984, 81, 1361.

8. Wang, L.; Price, H. L.; Juusola, J.; Kline, M.; Phanstiel, O. IV; J. Med. Chem. 2001, 44, 3682 and references therein.

9. Silva, E. T.; Cunha, A. S.; Lima, E. L. S.; Bioorg. Med. Chem. Lett. 2002, 12, 3207; Silva, E. T.; Fona, F. S.; Lima, E. L. S.; J. Braz. Chem. Soc. 2004, 15, 433.

10. Camara, C. A.; Pinto, A. C.; Rosa, M. A.; Vargas, M. D.; Tetrahedron 2001, 57, 9569.

11. Silva, T. M. S.; Camara, C. A.; Barbosa, T. P.; Soares, A. Z.; Cunha, L. C.; Pinto, A. C.; Vargas, M. D.; Bioorg. Med. Chem. 2005, 13, 193.

12. Fieser, L. F.; Fieser, M.; J. Am. Chem. Soc. 1948, 70, 3215; Fieser, L. F.; Hartwell, J. L.; Seligman, A. M.; J. Am. Chem. Soc. 1936, 58, 1223; Fieser, L. F.; Bader, A. R.; J. Am. Chem. Soc. 1961, 73, 681; Lee, K.; Turnbull, P.; Moore, H.W.; J. Org. Chem. 1995, 60, 461.

13. Di Chenna, P. H.; Benedetti-Doctorovich, U.; Baggio, R. F.; Garland, M. T.; Burton, G.; J. Med. Chem. 2001, 44, 2486.

14. da Silva, M. N.; Ferreira, V. F.; de Souza, M. C. B. V.; Quim. Nova 2003, 26, 407 freely available from the World Wide Web: http://quimicanova.sbq.org.br/qnol/2003/vol26n3/18.pdf.

15. Esteves-Souza, A.; Figueiredo, D.V; Esteves, A.; Câmara, C.A.; Vargas, M.D.; Pinto, A.C.; Echevarria, A.; unpublished results.

16. Ravelo, A. G.; Estévez-Braun, A.; Chávez-Orellana, H.; PérezSacau, E.; Mesa-Siverio, D.; Curr. Top. Med. Chem. 2004, 4, 241.

17. Fieser, L. F.; Martin, E. L.; Org. Synth. 1955 Coll. Vol. 3, 465; 1941 Annual Vol. 21, 56.

18. Experimental. To a solution of $\mathbf{1 a}(110.0 \mathrm{mg} ; 0.40 \mathrm{mmol})$ in $\mathrm{MeOH}(2 \mathrm{~mL})$ in a sealed tube at rt, was added a solution of $\mathbf{2 a}$ $(100.0 \mathrm{mg} ; 0.30 \mathrm{mmol})$ in $\mathrm{MeOH}(5 \mathrm{~mL})$. The reaction was stirred at $90{ }^{\circ} \mathrm{C}$ under argon, for $20 \mathrm{~h}$, after which time the solvent was removed under reduced pressure. The product was purified by flash chromatography (hexane/EtOAc, 9:1) and obtained as the reddish brown oil $\mathbf{2 b}(174.0 \mathrm{mg}, 75 \%) . \mathrm{R}_{\mathrm{f}}=$ 0.7 (hexane/EtOAc, 1:1). IR (film) $v_{\text {max }} / \mathrm{cm}^{-1}: 3347,3063,3027$, 2930, 2863, 1712, 1669, 1602, 1570, 1515, 1271, 721, 698. ${ }^{1} \mathrm{H}$ NMR (200 MHz, $\left.\mathrm{CDCl}_{3}\right): \delta 1.43(\mathrm{~s}, 9 \mathrm{H}), 1.60(\mathrm{~s}, 4 \mathrm{H}), 1.68$ (brs, 3H), 1.73 (brs, 3H), 2.42 (t, J $6.4 \mathrm{~Hz}, 2 \mathrm{H}$ ), 2.48 (t, J 6.4 $\mathrm{Hz}, 2 \mathrm{H}), 3.15$ (m, 2H), 3.36-3.45 (m, 4H), 3.52 (s, 2H), 5.06 $(\mathrm{m}, 1 \mathrm{H}), 5.25(\mathrm{~m}, 1 \mathrm{H}), 5.67(\mathrm{~m}, 1 \mathrm{H}), 7.56(\mathrm{dt}, J 7.5$ and 2.0 $\mathrm{Hz}, 1 \mathrm{H}$ ), 7.67 (dt, $J 7.5$ and $2.0 \mathrm{~Hz}, 1 \mathrm{H}$ ), 7.99 (dd, $J 7.5$ and $2.0,1 \mathrm{H})$ and $8.09(\mathrm{dd}, J 7.5$ and $2.0 \mathrm{~Hz}, 1 \mathrm{H}) .{ }^{13} \mathrm{C}$ NMR $(50$ $\left.\mathrm{MHz}, \mathrm{CDCl}_{3}\right): \delta 18.2,23.8,24.3,25.8,26.6,28.6,29.2,39.3$, 
45.0, 52.7, 53.4, 58.9, 77.9, 115.4, 123.2, 126.2, 127.2, 128.7, $130.5,132.0,133.6,134.4,139.4,145.7,156.1,183.1$. MS (QTof micromass spectrometer) Found: $560.3488[\mathbf{2 b + 1}]^{+}$. Calc. for $\left[\mathrm{C}_{34} \mathrm{H}_{46} \mathrm{~N}_{3} \mathrm{O}_{4}\right]^{+}$560.34883. Similar procedure was followed for the syntheses of compounds $\mathbf{3 b}$ and $\mathbf{4 b}$. Product 3b was purified as above using hexane/EtOAc 8:2 as eluent, and obtained as a brown-reddish oil. $3 \mathbf{b}(132 \mathrm{mg}, 61 \%) . \mathrm{R}_{\mathrm{f}}=$ 0.50 (hexane/EtOAc, 1:1). ${ }^{1} \mathrm{H}$ NMR (200 MHz, $\left.\mathrm{CDCl}_{3}\right): \delta 1.43$ (s, 9H), 1.48 (brs, 3H), 1.56-1.68 (m, 4H), 1.91 (brs, 3H), 2.38 (t, $J 6.5 \mathrm{~Hz}, 4 \mathrm{H}), 2.46(\mathrm{t}, J 6.5 \mathrm{~Hz}, 2 \mathrm{H}), 3.14(\mathrm{t}, J 6.2 \mathrm{~Hz}, 4 \mathrm{H})$, $3.52(\mathrm{~s}, 2 \mathrm{H}), 5.38(\mathrm{~m}, 1 \mathrm{H}), 5.92 \mathrm{~m}, 1 \mathrm{H}), 6.10(\mathrm{~m}, 1 \mathrm{H}), 7.26-$ $7.35(\mathrm{~m}, 5 \mathrm{H}), 7.55(\mathrm{dt}, J 7.5$ and $1.6 \mathrm{~Hz}, 1 \mathrm{H}), 7.63$ (dt, $J 7.5$ and $1.6 \mathrm{~Hz}, 1 \mathrm{H}), 8.03(\mathrm{dd}, J 7.5$ and $1.6 \mathrm{~Hz}, 1 \mathrm{H})$ and $8.06(\mathrm{dd}$, $J 7.5$ and $1.6 \mathrm{~Hz}, 1 \mathrm{H}) .{ }^{13} \mathrm{C} \mathrm{NMR}\left(50 \mathrm{MHz}, \mathrm{CDCl}_{3}\right): \delta 20.3$, 24.4, 25.6, 27.0, 28.1, 28.6, 28.7, 44.4, 53.0, 53.5, 59.0, 79.0, $113.5,118.1,126.2,126.5,127.2,128.5,129.0,130.1,132.1$, 133.8, 134.7, 138.7, 139.5, 144.8, 156.2, 183.1, 183.5. MS Found: $546.3332[\mathbf{3 b}+1]^{+}$. Calc. for $\left[\mathrm{C}_{33} \mathrm{H}_{44} \mathrm{~N}_{3} \mathrm{O}_{4}\right]^{+} 546.33318$. Product $\mathbf{4 b}$ was purified as above using hexane/EtOAc 8:2 as eluent and obtained as a brown-reddish oil (307.8.0 mg, 98\%). $\mathrm{R}_{\mathrm{f}}=0.43$ (hexane/EtOAc, 1:1). IR (film) $v_{\max } / \mathrm{cm}^{-1}: 3353,3063$, 3003, 2973, 2805, 1708, 1680, 1606, 1509, 1254, 1171, 729. ${ }^{1} \mathrm{H}$ NMR (200 MHz, $\left.\mathrm{CDCl}_{3}\right): \delta 1.44(\mathrm{~s}, 9 \mathrm{H}), 1,59(\mathrm{~m}, 6 \mathrm{H}), 2.43$ (t, J 6.2 Hz, 2H), 2.50 (t, J 6.2 Hz, 2H), $3.11(\mathrm{~m}, 4 \mathrm{H}), 3.53$ (s, 2H), 5.28 (brs, 1H), $5.68(\mathrm{~s}, 1 \mathrm{H}), 5.99(\mathrm{~s}, 1 \mathrm{H}), 7.30(\mathrm{~m}, 5 \mathrm{H})$, 7.61 (brt, $J 7.5 \mathrm{~Hz}, 1 \mathrm{H}), 7.73$ (brt, $J .5 \mathrm{~Hz}, 1 \mathrm{H}$ ), 8.05 (d, J 7.5 $\mathrm{Hz}, 1 \mathrm{H}), 8.11(\mathrm{~d}, J 7.5 \mathrm{~Hz}, 1 \mathrm{H}) .{ }^{13} \mathrm{C} \mathrm{NMR}\left(50 \mathrm{MHz}, \mathrm{CDCl}_{3}\right): \delta$ 24.6, 25.9, 26.1, 28.5, 34.0, 42.4, 52.4, 53.1, 58.9, 78.9, 126.2129.0, 131.9, 134.7, 139.2, 149.2, 157.3, 183.1, 184.3. MS Found: $492.2862[4 \mathbf{b}+1]^{+}$. Calcd for $\left[\mathrm{C}_{29} \mathrm{H}_{38} \mathrm{~N}_{3} \mathrm{O}_{4}\right]^{+} 492.28623$.
19. Relaxation assay of DNA topoisomerases I (topo I) and II- $\alpha$ (topo II- $\alpha$ ). Tðhe enzymatic activity was analyzed ${ }^{14}$ by the DNA relaxation assay according to the protocol described by topoGEN (topogGEN, Columbus, OH, USA). One unit of DNA topo I (from wheat germ, Sigma Co) and topo II- $\alpha$ (human recombinant in E. coli, Invitrogen) enzymes was incubated with $0.25 \mu \mathrm{g}$ of pBR322 DNA (Sigma Co), in the presence or absence of test compounds, in $10 \mu \mathrm{L}$ of a mixture containing $100 \mathrm{mmol} \mathrm{L}^{-1}$ Tris, pH 7.9, $500 \mathrm{mmol} \mathrm{L}^{-1} \mathrm{NaCl}, 500 \mathrm{mmol} \mathrm{L}^{-1}$ $\mathrm{KCl}, 50 \mathrm{mmol} \mathrm{L}^{-1} \mathrm{MgCl}_{2}, 1 \mathrm{mmol} \mathrm{L}{ }^{-1}$ EDTA, $0.15 \mathrm{mg} \mathrm{mL}^{-1}$ BSA and $10 \mathrm{mmol} \mathrm{L}^{-1}$ ATP for $30 \mathrm{~min}$ at $37^{\circ} \mathrm{C}$. The reaction was terminated by the addition of $1 \mu \mathrm{L}$ of a stop solution consisting of $50 \%$ glycerol, $10 \%$ sodium dodecyl sulfate (SDS) and $25 \%$ bromophenol blue. Electrophoresis was carried out over $1 \%$ agarose gel plates, equilibrated with TAE buffer $(50 \mathrm{x}$ stock: $242 \mathrm{~g}$ Tris-base, $57.1 \mathrm{~mL}$ glacial acetic acid and $100 \mathrm{~mL}$ of $0.5 \mathrm{~mol} \mathrm{~L}^{-1}$ EDTA) for $2.5 \mathrm{~h}$ at $60 \mathrm{~V}$. The gels were stained with ethidium bromide solution $\left(0.5 \mu \mathrm{g} \mathrm{mL}^{-1}\right)$ after electrophoresis for $30 \mathrm{~min}$, washed with water and photographed under UV light with a digital camera.

20. Wang, J. C.; Ann. Rev. Biochem. 1996, 65, 635.

21. Stewart, L; Champoux, J.J.; J. Methods Mol Biol. 2001, 95, 1.

22. Kashiwagi, K.; Tanaka, I.; Tamura, M.; Sugiyama, H.; Okawara, T.; Otsuka, M.; Sabado, T. N.; Williams, K.; Igarashi, K.; J. Pharmacol. Exp. Ther. 2004, 309, 884.

23. Suzuki, I.; Shigenaga, A.; Nemoto, H.; Shibuya, M.; Tetrahedron Lett. 2004, 45, 1955.

Received: October 13, 2005

Published on the web: April 24, 2006 